\title{
Compression Induced Intercellular Shaping for Some Geometric Cellular Lattices
}

\author{
Adonai Gimenez Calbo * and Amauri Alves Nery \\ Embrapa-Hortaliças, C.P. 0218, Brasília-DF, Brazil
}

\begin{abstract}
The wall perimeter fraction, which contact neighboring cells, was named compression ratio $(\alpha)$. A zero compression ratio indicates maximum intercellular (air) volume $\left(v_{G}, v / v\right)$ and neglectable contact among cells, while $\alpha=1$ indicates complete adherence between neighboring cells and no $v_{G}$ in the lattice. The maximum intercellular air volume $(\beta, v / v)$, when $\alpha=0$, was 0.593 for triangular, 0.2146 for square and 0,0931 for hexagonal lattices. The equation $\alpha=1-\left(v_{G} / \beta\right)^{1 / 2}$ was derived to relate $\alpha, \beta$ and $v_{G}$ in the studied lattices. The relation $\left(P_{S}=p / \alpha\right)$ between cell turgor $\left(P_{S}\right)$ and the tissue aggregating pressure $(p)$, defined as the compression to keep in place a layer of cells, was demonstrated using the compression ratio concept. Intercellular deformations of Ipomea batatas L. roots obtained with pressure chamber were used to test $\alpha, v_{G} p$ and $P_{S}$ as a function of compression. Volumetric and transversal elastic extensibilities and the lamella media tearing forces were obtained and $\boldsymbol{\alpha}$ constancy was considered as a criteria of cellular shape stability.
\end{abstract}

Key words: Elastic modules, compression, external force, intercellular air volume, Ipomea batatas, pressure chamber

\section{INTRODUCTION}

Internal and external forces shape the cells inside multicellular organs. Internally the turgor $\mathrm{P}_{\mathrm{S}}$ causes cell wall stretching (Lockhart, 1965) and the tearing forces between walls at the lamella media facing an intercellular air volume (Calbo et al., 1995), while the apoplasmic tension $\left(\mathrm{P}_{\mathrm{A}}\right)$ compresses the cell wall matrix (Calbo \& Pessoa, 1994) and conceivably have some cellular aggregating force. The action of external forces as cellular shaping agents seems to be less relevant than $\mathrm{P}_{\mathrm{S}}$ and $\mathrm{P}_{\mathrm{A}}$ but they are important during the plant development and in the post harvest life (Calbo et al., 1995) and were considered in studies about elastic extensibilities and hydraulic conductivity (Ferrie \& Dainty, 1976; Steudle et al., 1981).

Hulbary (1944) in a biometrical study of threedimensional shapes of cell considered that the formation of intercellular air volumes could be important to understand cellular shape determination. Most articles related to patterning and organ shaping, however, avoid the involvement of intercellular air volumes. Cummings (1996) to obtain a general geometric treatment of thick epithelial tissues discarded not only intercellular air volumes but also the cellular structure, which was loosely included in a mathematical framework.

In this work, intercellular air volume shaping of presumed identical flexible thin walled cells enclosed by hexagonal, square and triangular

\footnotetext{
*Author for correspondence
} 
lattice, in which individual cells were subjected to compression, were studied. The developed equations were used to obtain information about compression ratios, maximum lattice intercellular volume, elastic modules and lamella media tearing forces from assays in which the intercellular air volume of sweet-potato root was reduced with use an external compression.

\section{MATERIALS AND METHODS}

Sweet-potato roots $c v$. Princesa and Coquinho produced at Embrapa-Hortaliças (Brasília, DF) were covered by a plastic sealant and externally compressed. In such pressure chamber assays intercellular air volume deformation was estimated according to the amounts of air evolved through an air outlet (Calbo et al., 1995) or by a direct measurement of the organ deformation (Calbo \& Nery, 1994).

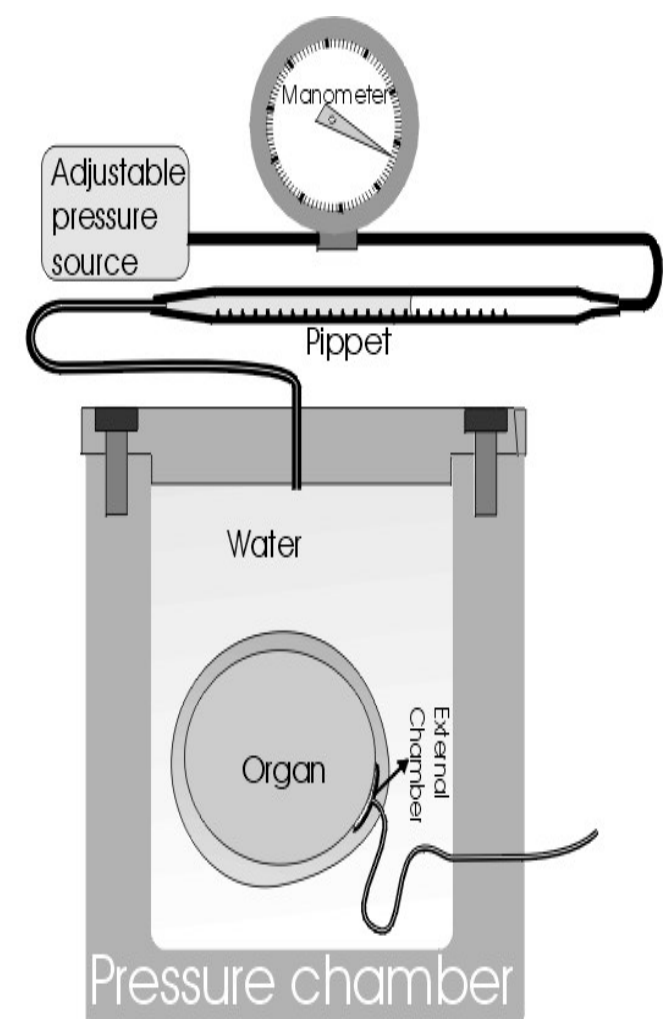

Figure 1 - Pressurized potometer to study intercellular air volume in compression assays.

The simplifyed pressurized potometer presented in (Fig. 1) allowed the direct measurement of the intercellular volume deformation caused by the external compression. In this potometer a low dead volume chamber (Nery \& Calbo, 1994) was attached to the organ covered with plastic sealant to allow the maintenance of barometric pressure inside the intercellular air volumes. Compression was applied to the water meniscus in the measuring pippet. Only pressures smaller than that required to remove the first droplet of apoplasmic sap in the capillary outlet (Fig. 1) were employed to respect the presumed $\mathrm{V}_{\mathrm{G}}$ deformation conditions, as close as possible.

Measurement of $V_{G}$ and $V_{C}$

The organ mass was measured and its empuxo after immersion in water was recorded. From mass and empuxo the organ volume was estimated according to the Archimedes principle. The total intercellular air volume $V_{G}$ was measured according to the maximum deformation of the organ in the potometric measurement (Calbo \& Nery, 1994) or according to the total amount of air removed from the compressed organ (Calbo \& Nery, 1994; Calbo et al., 1995). The volume of the cells $V_{C}$ was obtained as the difference between the organ volume $\left(\mathrm{V}_{\mathrm{o}}\right)$ and its intercellular air volume $\left(\mathrm{V}_{\mathrm{G}}\right)$.

\section{Physical approach}

The following simplifying assumptions were considered in this study:

1- A constant number of identical cells;

2- Each cell can be enclosed by a prism;

3- Thin and flexible cell walls not subjected to growth;

4- Intercellular air intrusions formed by lamella media border separation under the action of turgor dependent forces;

5- External compression affects uniformly the turgor of all cells in the tissue and

6- Temperature is constant.

Some of the geometric relations involved in the intercellular air volume shaping of a few particular cellular lattices are:

1- Intercellular air volumes $\left(\mathrm{V}_{\mathrm{G}}\right)$ at the corners of square prisms with side $\mathrm{S}$ (Fig. 2) can be approximated by :

$\mathrm{V}_{\mathrm{G}}=(4-\pi) \mathrm{Lr}^{2}$

in which, $r$ is the curvature radius of the cell wall facing $V_{G}$ and $L$ is the cell length.

2- For this square lattice one cell volume $\left(\mathrm{V}_{\mathrm{C}}\right)$ can be computed directly considering $\mathrm{s}$ as the part of 
the side S (Fig. 2), in which the considered cell touch its neighbor.

$\mathrm{V}_{\mathrm{C}}=\mathrm{L}\left(\pi \mathrm{r}^{2}+\mathrm{s}^{2}+4 \mathrm{sr}\right)=\mathrm{L}\left[\mathrm{S}^{2}-(4-\pi) \mathrm{r}^{2}\right.$

or as a difference between the prism volume $\left(\mathrm{LS}^{2}\right)$ and $\mathrm{V}_{\mathrm{G}}$ (Eq. 1)

$\mathrm{V}_{\mathrm{C}}=\mathrm{L}\left[\mathrm{S}^{2}-(4-\mathrm{p}) \mathrm{r}^{2}\right]$

3- The radius associated to $\mathrm{V}_{\mathrm{G}}$ (Fig. 2) $\mathrm{r}$ in Eq. 1 can be replaced by $(\mathrm{S}-\mathrm{s}) / 2$ :

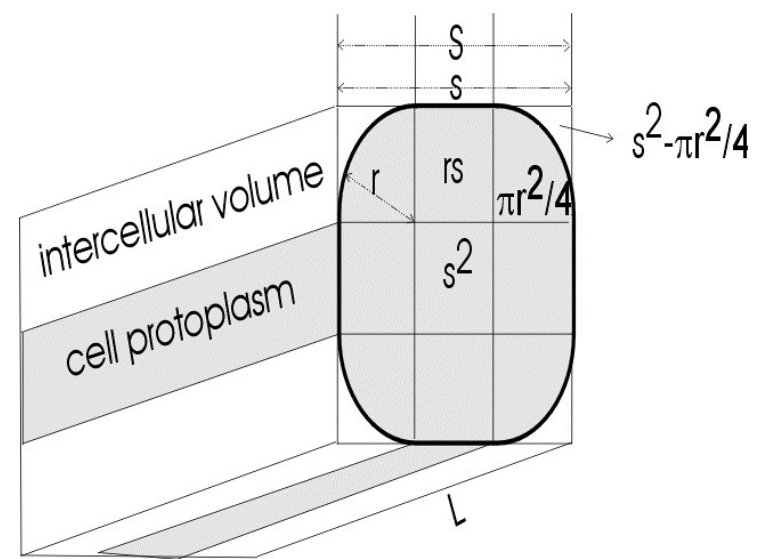

Figure 2 - Idealized cell, of length $\mathrm{L}$, enclosed by a square prism of side $\mathrm{S}$, facing identical cell neighbors, through plane $\mathrm{s}$ cross section. The cell wall curvature radius $\mathrm{r}$ faces an intercellular air volume. The areas expressed are a rectangle, a square, a quarter of a circle areas and a difference between a square of side $r$ and a quarter of a circle of radius $r$.

$\mathrm{V}_{\mathrm{G}}=\mathrm{L}\left(\mathrm{S}^{2}-2 \mathrm{sS}+\mathrm{s}^{2}\right)(4-\pi) / 4$

4- Defining compression ratio as $\alpha=\mathrm{s} / \mathrm{S}$ a relation between $\mathrm{V}_{\mathrm{G}}$ and $\alpha$ can be obtained dividing Eq. 4 by the prism volume $\left(V_{G}+V_{C}=L S^{2}\right)$ :

$\mathrm{v}_{\mathrm{G}}=\left(1-2 \alpha+\alpha^{2}\right)(4-\pi) / 4$

In Eq. $5 \mathrm{v}_{\mathrm{G}}=\mathrm{V}_{\mathrm{G}} /\left(\mathrm{V}_{\mathrm{G}}+\mathrm{V}_{\mathrm{C}}\right)$.

5- The analogous expression for a triangular cellular lattice is:

$\mathrm{v}_{\mathrm{G}}=\left(\frac{3}{2}-\frac{\boldsymbol{\pi}}{2 \sqrt{3}}\right)\left(1-2 \boldsymbol{\alpha}+\boldsymbol{\alpha}^{2}\right)$

and for an hexagonal cellular lattices is:

$\mathrm{v}_{\mathrm{G}}=\left(1-\frac{\pi}{2 \sqrt{3}}\right)\left(1-2 \boldsymbol{\alpha}+\boldsymbol{\alpha}^{2}\right)$

6- In Eq. 5, 6 and $7 \mathrm{v}$ is null when $\alpha=1$. The maximum $v_{G}(v / v)$ intrusion allowable, for $\alpha=0$, in these square, triangular and hexagonal lattices is the factor that relates $\mathrm{v}$ with $\left(1-2 \alpha+\alpha^{2}\right)$. As a consequence it seems relevant to suppose that the gaseous volume intrusion of an irregular cellular lattice could be related $\alpha$ by:

$\frac{V_{G}}{\boldsymbol{\beta}}=\left(1-2 \boldsymbol{\alpha}+\boldsymbol{\alpha}^{2}\right)$

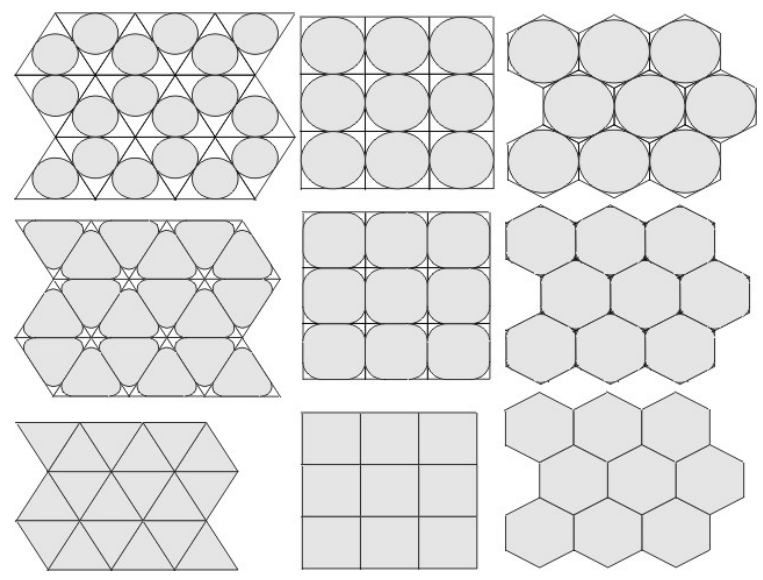

Figure 3 - Idealized behavior of cells arranged in cubic and hexagonal packing, without external compression with some compression and subjected to a compression larger than $\mathrm{P}_{\mathrm{S}}$.

in which $\beta$ is the maximum allowable $\mathrm{v}_{\mathrm{G}}(\mathrm{v} / \mathrm{v})$ intrusion and one of the roots of this equation is:

$\alpha=1-\left(v_{\mathrm{G}} / \beta\right)^{1 / 2}$

7- The crossection perimeter $b$ of these cells is:

$\mathrm{b}=2 \pi \mathrm{r}+4 \mathrm{~s}$

From Eq. 9 an expression for $b$ as a function of $v_{\mathrm{G}}$ can be obtained, after making $\mathrm{r}=(\mathrm{S}-\mathrm{s}) / 2$ and $\mathrm{s}=\alpha \mathrm{S}$.

$$
\mathrm{b}=\mathrm{S}\left[4-2 \sqrt{(4-\pi) v_{G}}\right]
$$

8- The ratio $\mathrm{V}_{\mathrm{G}} /\left(\mathrm{V}_{\mathrm{G}}+\mathrm{V}_{\mathrm{C}}\right)$ represented by $\mathrm{v}_{\mathrm{G}}$ depends only of the considered lattice (Fig. 3) and is independent of the cell size. From this fact, by induction, the following axiom was proposed: "Whole organs of any shape composed of prismatic cells arranged according to an uniform lattice can be treated as an unique cell having typical emptied $\mathrm{V}_{\mathrm{G}}$ corners, enclosed by one similar larger prism with the total organ volume". This axiom should be valid for volume related properties 


\section{Compression and aggregating forces}

A plane lamella between a pair of cells is an evidence that they have similar turgor and as a consequence a tissue composed of poliedric cells is an evidence of near turgor uniformity and of lamella media gluing forces. Without such gluing, the tissue should become a mass of ellipsoidal cells. The aggregating force $F$, which keeps in place a rectangular area sL of the cell wall herein considered (Fig. 2) can be related to the turgor $\mathrm{P}_{S}$ by:

$\mathrm{F}=\mathrm{P}_{\mathrm{S}} \mathrm{L} \mathrm{S}$

$\mathrm{F}$ can also be calculated as the product between average pressure $\mathrm{p}$ times the prism face SL (Eq. 13). This average pressure $p$ will be defined as the aggregating pressure.

$\mathrm{F}=\mathrm{p} \mathrm{S} \mathrm{L}$

A relation between turgor $\left(\mathrm{P}_{\mathrm{S}}\right)$ and $\mathrm{p}$ is then obtained replacing $\mathrm{s}$ by $\mathrm{S} \alpha$ in Eq. 12 and making it equal to 13:

$\mathrm{P}_{\mathrm{S}}=\mathrm{p} / \alpha$

If $p$ receive additions of an externally applied pressure $(\Delta$ p) then Eq. 14 can be rewritten as:

$\mathrm{P}_{\mathrm{S}}=\mathrm{P}_{\mathrm{S} 0}+\Delta \mathrm{P}_{\mathrm{S}}=\left(\Delta \mathrm{p}+\mathrm{p}_{0}\right) / \alpha$

In Eq. $15 p_{0}$ is a parameter $\left(\mathrm{P}_{\mathrm{S}_{0}} / \alpha\right)$ to be estimated from assays in which $\alpha$ (Eq. 9) is measured as a function of $\Delta \mathrm{p}$.

\section{Compression under nearly constant turgor}

When a force increment $\mathrm{dF}$ is applied to a cell layer (Fig. 2) without causing turgor $\left(\mathrm{P}_{\mathrm{S}}\right)$ and cell length (L) increase it, then, can be written as:

$\mathrm{dF}=\mathrm{d}(\mathrm{SLp})=\mathrm{P}_{\mathrm{S}} \mathrm{ds}$

According to Eq. 12 and 13 the division of Eq. 17 by SLp yields:

$$
\frac{\mathrm{d}(\mathrm{Sp})}{\mathrm{Sp}}=\frac{\mathrm{s}}{\mathrm{s}_{0}}
$$

Integration from $s_{0}$ to $s$ and from $\mathrm{S}_{0} \mathrm{p}_{0}$ to $\mathrm{Sp}$ generates:

$$
\frac{\mathrm{Sp}}{\mathrm{S}_{0} \mathrm{p}_{0}}=\frac{\mathrm{s}}{\mathrm{S}_{0}}
$$

using $\alpha(\mathrm{s} / \mathrm{S})$ an $\alpha_{0}\left(\mathrm{~s}_{0} / \mathrm{S}_{0}\right)$ Eq. 18 can be rewritten as:

$\mathrm{p}=\mathrm{p}_{0} \alpha / \alpha_{0}$
If $\alpha_{0}=1$ the substitution of Eq. 9 into Eq. 19 allows the representation of $\mathrm{v}_{\mathrm{G}}$ as a function of the external pressure $\Delta \mathrm{p}$ as:

$\mathrm{V}_{\mathrm{G}} / \beta=\left[1-\left(\mathrm{p}_{\mathrm{i}}+\Delta \mathrm{p}\right) / \mathrm{p}_{0}\right]$

In Eq. $20 \mathrm{p}$ is the initial aggregating pressure, $\Delta \mathrm{p}$ is the external pressure and $\mathrm{p}_{0}$ is the minimum compressive load required to keep in place the cells with zero intercellular volume.

\section{Constant cell volume compression}

For a cell with length $L$ and perimeter $b$ in a square lattice the transverse Hoockian elastic modules $(\varepsilon)$ is:

$$
\frac{\mathrm{db}}{\mathrm{b}}=\frac{\mathrm{d}(\mathrm{F} / \mathrm{L})}{\boldsymbol{\varepsilon}}
$$

Considering that $\mathrm{F}=\mathrm{pSL}$ the integration of Eq. 21 yields:

$$
\operatorname{Ln} \frac{\mathrm{b}}{\mathrm{b}_{0}}=\frac{\mathrm{p}_{0} \mathrm{~S}_{0}-\mathrm{pS}}{\boldsymbol{\varepsilon}}
$$

Replacing the $\mathrm{v}_{\mathrm{G}}$ expression of $\mathrm{b}$ (Eq. 11) equation 22 generates:

$$
\boldsymbol{\varepsilon} \operatorname{Ln}\left\{\frac{S\left[2-\sqrt{(4-\pi) v_{G}}\right]}{S_{0}\left[2-\sqrt{(4-\pi) v_{G 0}}\right.}\right\}=p S-p_{0} S_{0}
$$

If the ratio $\mathrm{a}=\mathrm{L} / \mathrm{S}$ is constant, then it can be substitued in Eq. 23 as $\mathrm{S}=\mathrm{a}^{-1 / 3}\left(\mathrm{~V}_{\mathrm{G}}+\mathrm{V}_{\mathrm{C}}\right)^{1 / 3}$. A numerical adjustment allows the fitting of $\mathrm{p}_{0}$ and $\varepsilon$, according to changes of $\mathrm{v}_{\mathrm{G}}$ caused by variations in the external pressure $(\Delta \mathrm{p})$. In this procedure $\mathrm{V}_{\mathrm{C}}$ remains constant by definition.

\section{Elastic volumetric modules and $V_{G}$}

In a compression assay the organ volume $\left(\mathrm{V}_{\mathrm{G}}+\mathrm{V}_{\mathrm{C}}\right)$ reduction is functionally associated to an elastic volumetric elastic modules $\mathrm{E}$ by:

$\frac{d V_{G}}{V_{G}+V_{C}}=-\frac{d p}{E}$

The integration of Eq. 24 yields:

$\operatorname{Ln} \frac{\mathrm{V}_{\mathrm{G}}+\mathrm{V}_{\mathrm{C}}}{\mathrm{V}_{\mathrm{G}_{0}}+\mathrm{V}_{\mathrm{C}}}=\Delta \mathrm{p} / \mathrm{E}$

A different equation could be written, considering only the elastic modules $\mathrm{E}_{1}$ associated to the walls surrounding the intercellular air volume.

$\mathrm{dV}_{\mathrm{G}} / \mathrm{V}_{\mathrm{G}}=\mathrm{dp} / \mathrm{E}_{1}$

Eq. 26 is integrated to: 
$\operatorname{Ln}\left(\mathrm{V}_{\mathrm{G}} / \mathrm{V}_{\mathrm{G} 0}\right)=\Delta \mathrm{p} / \mathrm{E}_{1}$

\section{Plant size and turgor at constant $\alpha$}

For an uncompressed organ in which $\mathrm{a}=\mathrm{L} / \mathrm{S}$ and $\mathrm{C}=\mathrm{b} / \mathrm{S}$ are constants, $\alpha$ should not change as a function of turgor and the integration of Eq. 21, in this particular condition yields:

$\varepsilon \operatorname{Ln~S}^{2} / \mathrm{S}_{0}{ }^{2}=\mathrm{a} \mathrm{S}^{2} \mathrm{P}_{\mathrm{S}}-\mathrm{a} \mathrm{S}_{0}{ }^{2} \mathrm{P}_{\mathrm{S} 0}$

from which turgor can be separated as:

$\mathrm{P}_{\mathrm{S}}=2 \varepsilon / \mathrm{S}^{2} \operatorname{Ln} \mathrm{S} / \mathrm{S}_{0}-\mathrm{S}_{0}^{2} \mathrm{~S}^{2} \mathrm{P}_{\mathrm{S} 0}$

\section{RESULTS AND DISCUSSION}

The curve of $\mathrm{v}_{\mathrm{G}}$ reduction as a function of the applied external compression was smoother (Fig. 4) than the method of collecting the air removed in the outlet. Additionally, this method do not have the problems of gas solubilization previously acknowledged by Calbo et al. (1995). For this reason the results obtained with the potometric method using the equipment illustrated in Fig. 1 should be preferred.

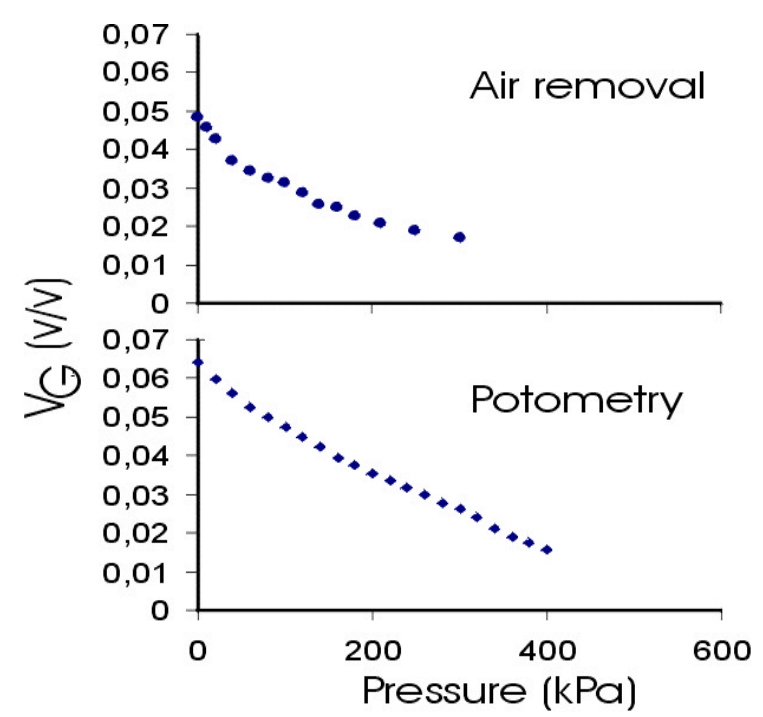

Figure 4 - Typical $v_{G}(v / v)$ measurements of sweetpotato roots as a function of compression obtained by pressurized measurements of potometry and a air extracted volume from the same compression assay.

$V_{G}$ compression under presumed constant turgor The reduction of $v_{G}$ with compression for the constant turgor model, yield good fitting (Table 1). Most of the experimental variation (>99\%) was explained by this model, which conveys to the idea that the equation is valuable despite of some significant unexplained residual components. To fit Eq. $20 \beta$ was set to $(4-\pi) / 4$, because the additional fitting of $\beta$ caused no goodness of fit improvement, and the estimated $\beta$ values were close to this theoretical value.

This constant turgor model yield an aggregating pressure $\mathrm{p}_{i}$ of $700 \mathrm{kPa}$ and an estimated turgor $\mathrm{p}_{\mathrm{o}}$ of $\cong 1200 \mathrm{kPa}$.

\section{Elastic cell wall extension}

Equation 23 was developed to represent $\mathrm{V}_{\mathrm{G}}$ versus compression for a repeating cellular lattice in which the cell crossection area remains constant while the walls are elongated by the stretching caused by turgor increase in the compressed tissue. The compression induced $\mathrm{V}_{\mathrm{G}}$ reduction in this case is associated to the cell wall perimeter (b) increase, which causes the turgor increase.

The elastic modules $\varepsilon$, the tissue initial aggregating pressure at the beginning of the compression assay $p_{1}$ and the turgor of the cells at the point where $\mathrm{v}_{\mathrm{G}}$ is zeroed $\left(\mathrm{p}_{\mathrm{O}}\right)$, were obtained during the computational fitting (Table 1). For studies of organs subjected to external compression (Eq. 23) and for pressure volume dendrometric studies (Eq. 29) the Hoockian elastic modules $(\varepsilon)$ seems to be of potential interest.

In these compression assays no water was lost but some water exchange between the symplasm and apoplasm may have occured. The adjustment for $\mathrm{v}_{\mathrm{G}}$ versus pressure under presumed constant cell volume (symplasm volume, Eq. 23) was better than for cells at presumed constant constant turgor (Table 1). The improvement, however, was minor and could be explained considering the transverse cell wall elastic modules.

The aggregating pressure $\left(\mathrm{p}_{\mathrm{i}}=584 \mathrm{kPa}\right)$ in this model was slightly smaller than the constant turgor model. The turgor estimated at $\mathrm{v}_{\mathrm{G}}=0\left(p_{O}=1440\right.$ $\mathrm{kPa}$ ) was not significantly different from the one obtained using the constant turgor model. The linear elastic modules $(3248 \mathrm{~N} / \mathrm{m})$ value was about ten times as large as the values reported for Chara carollina (Steudle et al., 1991). No similar results were found for other storage roots. 
Table 1- Average coefficients $(n=5)$ and mean standard deviation for physical models adjusted to ten assays of $V_{G}$ reduction versus compressive load $(\Delta \mathrm{p})$, performed with sweet potato cv Princesa using a pressurized potometer and five with cv Coquinho using the amounts of air removed during compression assays.

\begin{tabular}{|c|c|c|c|c|}
\hline \multirow{2}{*}{ Parameter } & \multicolumn{2}{|c|}{ cv. Princesa } & \multicolumn{2}{|c|}{ cv Coquinho } \\
\hline & mean + se & $\mathrm{R}^{2}$ (average) & meantse & $\mathrm{R}^{2}$ (average) \\
\hline \multicolumn{5}{|c|}{ Volumetric elastic modules $\mathrm{E}$ of the organ $\left[\mathrm{v}_{\mathrm{G}}=\exp (\Delta \mathrm{p} / \mathrm{E})-\mathrm{v}_{\mathrm{C}}\right]$} \\
\hline $\mathrm{v}_{\mathrm{Co}}(\mathrm{v} / \mathrm{v})$ & $0.9433 \pm 0.0036$ & \multirow{2}{*}{0.976} & $0.9593 \pm 0.0014$ & \multirow{2}{*}{0.925} \\
\hline $\mathrm{E}_{1}(\mathrm{kPa})$ & $8302 \pm 353$ & & $9844 \pm 1369$ & \\
\hline \multicolumn{5}{|c|}{ Volumetric elastic modules $\mathrm{E}_{1}$ from the walls surrounding $\mathrm{V}_{\mathrm{G}}\left[\mathrm{v}_{\mathrm{G}}=\mathrm{v}_{\mathrm{Go}} \exp \left(-\Delta \mathrm{p} \mathrm{E}_{1}\right)\right]$} \\
\hline $\mathrm{v}_{\mathrm{Go}}(\mathrm{v} / \mathrm{v})$ & $0.0609 \pm 0.0030$ & \multirow{2}{*}{0.993} & $0.0431 \pm 0.0015$ & \multirow{2}{*}{0.973} \\
\hline $\mathrm{E}(\mathrm{kPa})$ & $295.0 \pm 30.5$ & & $258 \pm 35$ & \\
\hline \multicolumn{5}{|c|}{$\mathrm{V}_{\mathrm{G}}$ compression under constant cell turgor $\left\{\mathrm{v}_{\mathrm{G}}=0.2146\left[1-\left(\mathrm{p}_{\mathrm{i}}+\Delta \mathrm{p}\right) / \mathrm{p}_{\mathrm{o}}\right]^{2}\right\}$} \\
\hline $\mathrm{p}_{\mathrm{i}}(\mathrm{kPa})$ & $678.5 \pm 32.7$ & \multirow{2}{*}{0.9901} & $819.5 \pm 127.0$ & \multirow{2}{*}{0.9538} \\
\hline $\mathrm{p}_{\mathrm{o}}(\mathrm{kPa})$ & $1430 \pm 89$ & & $1460 \pm 208$ & \\
\hline \multicolumn{5}{|c|}{$\mathrm{V}_{\mathrm{G}}$ compression for cells with elastic walls in the absence of water exchange (Eq. 23) } \\
\hline $\mathrm{p}_{\mathrm{i}}(\mathrm{kPa})$ & $584.4 \pm 26.0$ & \multirow{3}{*}{0.9921} & & \\
\hline $\mathrm{p}_{\mathrm{o}}(\mathrm{kPa})$ & $1440 \pm 86.0$ & & & \\
\hline$\varepsilon(\mathrm{N} / \mathrm{m})$ & $32486 \pm 3180$ & & & \\
\hline
\end{tabular}

The aggregating pressure estimates similarities between these models were encouraging considering the conceptual difficulties involved. The differences were of less than $10 \%$ for aggregating pressures and were within the experimental errors for turgor at $\alpha=1$.

Tissues with thin walled cells under stable $\mathrm{V}_{\mathrm{G}}$, presumed from compression ratio $(\alpha$ constancy in the absence of external compression turgor can be evaluated from $\varepsilon$. To use Eq. 29 the side $S$ (or diameter) with an Alvim (1975) dendrometer, a LVDT (Klepper et al., 1972) or volumetric measurements are needed. Conversely given estimates of turgor Eq. 29 allows the estimation of the linear elastic modules of plant cells according to the restrictive assumptions used in this work.

Considerations about volumetric elastic modules The volumetric elastic modules (E) for the whole organ under compression (Eq. 25) yielded the worst adjustment (Table 1). The volumetric elastic modules $\mathrm{E}_{1}$ associated to the cell wall facing $\mathrm{V}_{\mathrm{G}}$ (Eq. 27) gave a better adjustment (Table 1), because the elasticity of the walls facing $\mathrm{V}_{\mathrm{G}}$ is related to the external pressure response.
The values of the volumetric elastic modules E, for organ compression, and the volumetric elastic modules $\mathrm{E}_{1}$, for compression of the walls around $\mathrm{V}_{\mathrm{G}}$ depend on the turgescence intercellular air volume and cell wall elasticity. Differently, intercellular air volume are excluded as a variable in the volumetric elastic modules obtained by changing the cell water content and using a pressure-chamber (Murphy \& Ortega, 1996) or using a pressure probe (Murphy \& Ortega, 1995). Calbo et al. (1995) acknowledged that in external compression assays, similarly to pressurizing a fruit between two fingers, which causes cellular deformations not involved in other methods to evaluate organ elasticity.

\section{$V_{G}$ formation spontaneity}

One procedure to consider $\mathrm{V}_{\mathrm{G}}$ formation spontaneity is by evaluating free energy reduction. In the first ideal system from this article, turgor was considered to be constant and the free energy reduction $(w)$ caused by formation of intercellular air volumes is:

$\mathrm{w}=\mathrm{P}_{\mathrm{S}} \Delta \mathrm{V}_{\mathrm{C}}$ 
For the second model, the cell volume was considered to remain constant and $\mathrm{V}_{\mathrm{G}}$ formation, as consequence, is related to the elastic work produced, free energy reduction, while the cell perimeter is reduced from $b$ to $b_{b}$ according to Eq. 31.

$\mathrm{w}=\varepsilon\left(\mathrm{b}^{2}-\mathrm{b}_{0}{ }^{2}\right) / 2$

Another valuable form to consider the $V_{G}$ formation spontaneity is by estimating the tearing tension at the lamella media. In the absence of an external compression, the tearing tension per unit of cell length $\left(T_{L}=F / L\right)$ acting at one of the two lamella media bordering points that determine the segment $\mathrm{s}$ in Fig. 2 is the force $\left(\mathrm{F}=\mathrm{sLP}_{\mathrm{S}}\right)$ divided by 2 times the cell length (L).

$\mathrm{T}_{\mathrm{L}}=\mathrm{s} \mathrm{P}_{\mathrm{S}} / 2$

Meristematic tissues are geometrically similar to soap bubbles (Sifton, 1945 and 1957) in which intercellular air volumes can not be observed at an optical microscope. The tissue pattern changes during differentiation, and intercellular air volumes are gradually developed among the plant cell walls. Possibly cell growth associated or not to a lamella media biochemical weakening, which increase its susceptibility to the turgor dependent tearing forces (Eq. 32) acting at the corners among three or more cells (Jeffree et al., 1986), play an important whole in the development of intercellular air volume intrusions.

An inspection of Eq. 32 associated to other previously considered geometric considerations allows the following inferences about tearing forces at the lamella media and the development of intercellular air volume intrusions:

1- The smaller the cells, the smaller are the tearing forces at their corners;

2- The tearing forces reduce as $\mathrm{v}_{\mathrm{G}}$ increases (Eq. 9 and 14);

3- Cell separation occurs as the tearing tension is being reduced to a threshold limit. This threshold should be under strict plant molecular control.

In sweet-potato roots, tearing force was estimated in $6 \mathrm{~N} / \mathrm{m}$ at the lamella media $\mathrm{V}_{\mathrm{G}}$ edge. A resistance to a tension of this magnitude or even larger is required to assure $V_{c}$ stability. From a macroscopic perspective such ${ }^{\mathrm{G}} \mathrm{V}_{\mathrm{G}}$ stability could be stated as "The intercellular volumes remains stable while the compression ratio $\alpha$ remains constant". This inference should be valid in absence of applied external compression in nongrowing tissues.

\section{ACKNOWLEDGMENTS}

This research was supported by research grants from the Brazilian Scientific and Technological Council (CNPq).

\section{RESUMO}

A fração do perímetro da parede celular em contato com células vizinha foi denominada razão de compressão $(\alpha)$. Razão de compressão zero indica volume intercelular $\left(\mathrm{v}_{\mathrm{G}}, \mathrm{v} / \mathrm{v}\right)$ máximo $\mathrm{e}$ contato neglível entre as células, enquanto $\alpha=1$ ocorre quando há completa aderência com as células vizinhas $\left(\mathrm{v}_{\mathrm{G}}=0\right)$. $\mathrm{O}$ volume (gasoso) intercelular máximo $(\beta, \mathrm{v} / \mathrm{v})$, quando $\alpha=0$, foi $0,593,0,2146$ e 0,0931 para látices triangulares, quadradas e hexagonais. A equação derivada para relacionar $\alpha, \beta$ and $v_{G}$ nas látices estudadas foi $\alpha=1-\left(\mathrm{v}_{\mathrm{G}} / \beta\right)^{1 / 2}$. A razão de compressão foi em seguida empregada para estabelecer a relação $\mathrm{P}_{\mathrm{S}}=\mathrm{p} / \alpha$ entre a pressão de turgescência $\left(\mathrm{P}_{\mathrm{S}}\right)$ e a pressão de agregação (p), definida com a compressão para manter uma camada de células no seu lugar. As deformações intercelulares de batatadoce obtidas com procedimentos de câmara-depressão foram empregados para obter informações sobre as variações de $\alpha, v_{G}$, p e $P_{S}$ em função da compressão empregando módulos de elasticidade transversal e volumétrico. A constância de $\alpha$ foi sugerida como critério de estabilidade de látices celulares.

\section{REFERENCES}

Alvim, P.T. (1975) A new dendrometer for monitoring cambium activity and changes in the internal water status of plants. Turrialba, 25, 445-447.

Calbo, A.G. \& Nery, A.A. (1995) Medida de firmeza de cenoura e tomate por aplanação. Hort. Bras., 12, 1418.

Calbo, A.G. \& Nery, A.A. (1994) Methods to measure gaseous volume in plants. R. Bras. Fisiol. Veg., 6, 153-162.

Calbo, A.G. \& Nery, A.A. (1995) Methods for measurement of gas volume of fruits and vegetables. J. Amer. Soc. Hort. Sci., 120, 217-221. 
Calbo, A.G.; Nery, A.A. \& Herrmann, P.S.P. (1995) Intercellular deformation in compressed organs. Ann. Bot., 76, 365-370.

Calbo, A.G. \& Pessoa, J.D.C. (1994) A plant growth reanalysis. An extension of Lockhart's equation to multicellular plants. R. Bras. Fisiol. Veg., 6, 83-89.

Cummings, F.W. (1996) Geometrical concepts in epithelial sheets. J. Theor. Biol., 179, 41-48.

Ferrier, J.M. \& Daint, J. (1977) A new method for measurement of hydraulic conductivity and elastic coefficients in higher plant cells using an external force. Can. J. Bot., 55, 858-866.

Hulbary, R.L. (1944) The influence of air spaces on the three-dimensional shapes o cell in elodea stems, and a comparison with pith cells of Ailanthus. Amer. J. Bot., 31, 561-579.

Jeffree, C.E.; Dale, J.E. \& Fry, S.C. (1986) The genesis of intercellular spaces in developing leaves of Phaseolus vulgaris L. Protoplasma, 132, 90-98.

Klepper, B.; Douglas Browning, V. \& Taylor, H.M. (1971) Stem diameter in relation to plant water status. Plant Physiol., 48, 683-685.

Lockhart, J.A. (1965) An analysis of irreversible plant cell elongation. J. Theor. Biol., 8:264-275, 1965.
Murphy, R. \& Ortega, J. K. E. (1995) A new pressure probe method to determine the average volumetric elastic modulus of cells in plant tissue. Plant Physiol., 107, 995-1005.

Murphy, R. \& Ortega, J. K. E. (1996) A study of the stationary volumetric elastic modulus during dehydration and rehydration of stems of pea seedlings. Plant Physiol., 110, 1309-1316.

Nery, A.A. \& Calbo, A.G. (1994) Adaptation of the constant volume manometry for the study of gas exchange by bulk hole organs. J. Amer. Soc. Hort. Sci., 119, 1222-1229.

Steudle, E.; Ferrier, J.M. \& Dainty, J. (1981) Measurements of the volumetric and transverse elastic extensibilities of Chara carollina internodes by combining the external force an pressure probe techniques. Can. J. Bot., 60, 1503-1511.

Steudle, E.; Zimmermann, U. \& Luttge, U.E. (1977) Effect of turgor pressure and cell size on the wall elasticity of the plant cells. Plant Physiol., 59, 285289.

Received: August 17, 1999; Revised: October 26, 1999 ; Accepted: July 12, 2000. 